\title{
The Role Perceptions of Newly Appointed Senior School Leaders in the Western Cape, South Africa and Abu Dhabi United Arab Emirates: A Comparative Case Study
}

\author{
Nelius Jansen van Vuuren ${ }^{1}$ \\ Center for International Teacher Education, CPUT, South Africa. \\ Villa 5, Street 51, Khalifa City A, Abu Dhabi, UAE.
}

Received: May 13, 2018 Accepted: May 29, 2018 Online published: June 18, 2018

doi:10.5296/ijhrs.v8i3.13293 URL: https://doi.org/10.5296/ijhrs.v8i3.13293

\begin{abstract}
The role of the senior school leader, in school leadership teams, has been intensely deliberated over the years. Professional learning and leadership approaches and experiences for newly appointed senior school leaders have been extensively linked to the role perceptions of new school leaders. The importance of appropriate recommendations for policy and practice highlight the need for complex developmental support ingenuities to support their perceived development needs. Extensive teaching experience may be the only requirement for being appointed as a senior school leader, as also suggested by the Western Cape Education system (WCED). A developing system such as the Abu Dhabi Education Council (ADEC) system, highly qualified individuals make up for a lack of experience. Both these perceptions support the notion that no further professional development is required for newly appointed school leaders, the problem addressed in this paper. This article report and compare the main findings of the perceived roles and responsibilities of newly appointed senior school leaders in the Western Cape, South Africa, and Abu Dhabi, United Arab Emirates (UAE). The perceived roles and responsibilities of newly appointed school leaders, suggest a unique and specialist development approach to support effective leadership. The outcomes of this study further suggest a need for contextualised, individualised training and

1 Nelius is a school improvement advisor and coach and mentor for school leaders internationally. He developed school improvement frames and leadership development frames for changing school systems.
\end{abstract}


support in their individualised roles and responsibilities. The paper, therefore, employs a mixed-method approach to gather data to understand the perceived roles and responsibilities of newly appointed senior school leaders in the Western Cape, South Africa and Abu Dhabi, UAE.

Keywords: newly appointed senior school leaders, school leadership and management, professional development programmes, role perceptions of school leaders

\section{Introduction}

The government schooling system in South Africa has been constantly the victim of change initiatives creating a fragmented, and quoted as largely dysfunctional, and lacking in innovation and direction. This has as a result the outcome of low education standards. The development strategies of newly appointed senior school leaders in the Western Cape are a result of their own individual perceptions of their roles. A lack of contextualised training to support the new school leaders' perceptions, result in them failing to engage with pupils, and manage their schools effectively while managing the forever changing system. The Abu Dhabi system, a very young and developing system is playing catch-up with the rest of the world, and as such suffer from unique situations created by a system forever changing and seeking the best way forward for their nation. The lack of experience in this young system results in a perceived roles and responsibility perception from their school leaders that suggest their current approach to professional development does not cater for their development needs.

The establishment of professional learning and leadership approaches for newly appointed senior school leaders determined the human resource development focus for this article. The retention of highly talented senior leaders is dependent on dedicated contextualised development programs, to empower school leaders to drive instructional leadership and to meet challenges such as structured learning opportunities that promote quality education in both the South African and UAE schools. This objective is achieved by way of developing the competency of education leaders who apply critical understanding, values, knowledge and skills to school leadership and management, within the vision of democratic transformation that contributes to improving the delivery of education across both school systems.

Effective senior school leadership is crucial for school and system effectiveness and, in particular, also for school learner success (Renihan, 2012). This article attempts to address the assessment that both systems, although well established in the Western Cape, South Africa and developing in Abu Dhabi, are in need of major reform through educational leadership development. The role of the senior school leader is undeniably demanding, diversified, complex, forever changing, and encompasses high levels of responsibility (Clifford, 2010; Leithwood \& Riehl, 2003). In this regard, Hess and Kelly (2007) summarise the important role of senior school leaders in the following way:

In a new era of accountability, where school leaders are expected to demonstrate bottom-line results and use data to drive decisions, the skill and 
knowledge of Principals matter more than ever (Hess \& Kelly, 2007:1).

This article, draws on data from a doctoral study where twenty newly appointed senior school leaders in the Western Cape, and twenty newly appointed senior school leaders in Abu Dhabi, engage with their roles and responsibilities perceptions after being newly appointed into their new roles. This research study builds on the research project reported on by Piggot-Irvine, Howse and Richard (2013), which investigated the role perceptions, workload and leadership needs of South African senior school leaders in the Gauteng Province. While the focus of their study was solely on the senior school leaders' development needs, this study focuses specifically on the perceived roles and responsibilities of newly appointed school leaders in the Western Cape and Abu Dhabi. The purpose in writing this article was to make available data, gathered from interviewing 20 novice school leaders from different school contexts in the Western Cape, South Africa and Abu Dhabi, UAE, to expand on the suggestion that development programmes lack the developmental focus it is supposed to have.

This article departs providing the background and rationale for the study followed by a discussion on current international and national literature about the roles and responsibilities of novice school leaders. Thereafter it describes the methodology and research design that informed the study. In the main discussion section, the article presents the findings of the study, based on leadership functions used to determine effective school leaders. These leadership functions were adapted from leadership development frameworks by Cranston et al (2003), Hess and Kelly (2007) and Piggot-Irvine et al (2013), as well as the norms and standards for school leaders from the DoE (2011). This article presents the outcomes of a doctoral study of completed surveys and follow up interviews. The article closes with a discussion of the findings in conjunction with pertinent literature, and further proposed recommendations for the continued development of new senior school leadership skills in the Western Cape, South Africa and Abu Dhabi, UAE.

\section{Professional Development for New Senior School Leaders}

Although much evidence exist on the organizational proficiency of established senior school leaders, relevant literature on the role and responsibility perceptions of newly appointed senior leaders has not been well documented both within South African and the UAE school contexts. Both nations are involved in constant change, in particular bringing forward their vision for the future of both education systems. The priorities for developing leadership skills for novice school leaders in South Africa and the UAE show clear similarities which include the setting of clear goals, structured and well managed and designed curricula, monitoring lesson plans, allocating resources and evaluating teachers on a regular basis to promote quality teaching and learning. Both systems identified the need for quality instruction and overall strategic management as priorities for developing leadership skills in particular for the novice senior school leader. This need for radical change is imperative, the forever fast changing world adds pressure on education systems to keep up with the latest teaching and learning practices. Conventional teaching learning models does not support the need for individualized student teaching plans, nor acknowledging the unique way in which children learn. It is therefore critical for revised education systems to recognize that young people are 
individuals with a desire for their own knowledge assimilation. Consequently, it should be recognized and acknowledged that children do not learn in the same way. It is agreed that children should have exposure to basic essential skills and knowledge, although it is understood and that the education leaders from both systems should explore diverse variables of subject matter so that children may develop in their own particular way.

Cranston (2003) and Piggot-Irvine (2013) agree that the lack of scholarly inquiry into the roles and responsibilities and the perceptions of novice school leaders of these roles and responsibilities are highlighted as one of the causes for the shortcomings of existing school leadership programme studies conducted in New Zealand and South Africa. Newly appointed school leaders development varies between on-the-job training, but in most cases range from carefully planned training and induction programmes supported by formal classroom focused formal workshops, individualised courses, and coaching or mentoring in learning communities by established peers (Normore 2004; Hart 1993; Sergiovanni 2001; Fullan 2014).

The author recognises that for school leaders to be visionary they constantly have to adapt to stay abreast of change to meet future standards. Sutcliffe (2013) concur and further suggest that qualities needed to be a successful school leader are vision, courage, passion, emotional intelligence, judgement, resilience, and curiosity, he further states that successful school leaders show great determination and are steadfast in challenging scholars' under-performance or poor behaviour by taking an active interest in their work and that of their staff. It is suggested that senior school leaders should be team-builders, leading the community while providing developmental socio-economic and pastoral care support. School leaders are also great motivators in getting people to go that extra mile to achieve objectives (ibid).

Great disparity exists between the definition of leadership and the content of leadership development programmes. This creates a significant challenge for the design and implementation of leadership training courses. What follows is a brief discussion of some frameworks for leadership development and highlights their incongruences.

An array of scholars support the urgent need for a serious rethink and revision of school leader training programmes to provide a better means of preparing participants for the responsibilities, challenges and opportunities they will face at school (Elmore, 2000; Hess 2003; Murphy, 2001; Tucker, 2003). Researchers agree that socialisation or professional development programmes should be well planned, supported, and monitored to support successfully the newly appointed senior school leaders. Leadership development is defined as expanding the collective capacity of organisational members to engage effectively in leadership roles and processes (McCauley et al., 1998). Professional development for school leaders has been defined as ranging from formal training sessions to informal interactions between Principals and teachers and amongst Principals themselves (Quint et al., 2007).

While leadership is foregrounded, the management aspect of the school leader's office is fully embedded within the role, because, it is believed that effective leadership supersedes efficient management. The leader should adopt characteristics of management because it 
accepted that school leadership should comprise more leadership characteristics than management traits (as described by Kotter, 1990). This approach is supportive of the Victoria leadership development model, based on Sergiovanni's (2001) model for leadership development, in which the management functions take preference. In contrast, the new framework for this study seeks to balance management and leadership functions.

While Guskey (2003), Hess \& Kelly (2007) and Normore (2004) agree that new school leaders need induction into their roles, the aims, content, development strategies and assessment of such endeavours are actively debated, resulting in disparate approaches to leadership development internationally. Experts in leadership show very little common understanding of the concept of 'leadership-leaders' (Hoy \& Miskel, 2008). There is a great need for clarity in both the conceptualisation of leadership and the approaches to leadership development. There is also need to develop a conceptual framework to evaluate both the implementation and progress of professional leadership development and how this development influences teachers' operational habits and students' learning practices (Desimone, 2009).

According to Bush (2007) and Fullan (2006), leadership can be defined as a process in which a person has the support of others to realise a shared goal. Put simply, a leader can be someone who is followed by others, or someone who leads guides and directs others. Anderson (1998) define leadership as "organising people to reach a common shared goal" (p.12). Leadership focuses mainly on mission, direction and inspiration, with its associated aspects of articulating a negotiated vision, developing shared ownership and developing democratic evolutionary plans. Leadership studies have produced theories which include vision, structures, functions, behaviour, values and other attributes to effect change (Fullan, 2009). The author concurs but further suggest that; school leadership can be defined as the symbiotic interaction between the strategic leadership functions and the organisational functions in a school. Strategic leadership involves functions such as planning, budgeting, organising and staffing issues, while dealing with the day-to-day operational running of the school is considered an organisational or managerial function. Leithwood and Riehl (2003) and Roza (2003) suggest that a challenge for the new school leader is the ability to manage the balance between the strategic and organisational functions of their roles. These roles cannot be separated because the functions often run concurrently; for example, decisions relating to the vision and mission of the school, affect long-term activity as part of strategic leadership. Since daily operational decisions have a direct impact on the 'here-and-now' strategic leadership constitutes the organisational function of school leaders, and both need to run concurrently in order for effective leadership to take place (ibid). These authors further suggest that it is normal for new senior school leaders to tend to respond to the more urgent day-to-day matters when leading the organisational function of a school, and that this can result in them neglecting the 'leading strategically' function of their new roles (Leithwood \& Riehl, 2003; Roza, 2003, Fullan, 2014).

Literature published by the Western Cape Education Department (WCED), consistently mentioned the importance of senior school leaders to assimilate with their ability to lead schools strategically. They place leading teaching and learning as a management function as 
critical function of leading schools. The same document however place a lower value on managing human resources (staff) in the school and managing the school as an organization (WCED, 2015; DoE, 2011). This is supported by the National Education Policy Act 27 of 1996 in South Africa (South Africa Department of Education, 2011a), where the school leader is highlighted as the person that has the overall responsibility for leading and managing the school. The same literature recognize that these senior school leaders must be well trained and appropriately developed through well designed contextualized developmental programmes.

It is well documented and understood throughout the literature that the developmental needs off developed and newly appointed senior leaders have, are in most cases different. If the two cases in this study, Abu Dhabi and Western Cape are evaluated, it is clear that role and development perceptions may be different as a result of acquired skill sets and experience levels or a lack thereof. The main attribute as per the DOE (2011), is to provide instructional leadership based on a focused mission for the school, creating a culture for learning, setting goals for learning, making sure instruction is consistently of a high quality, and measuring student outcomes.

The literature suggests that there is considerable similarity in school leadership programmes offered worldwide, affirming the view that an international curriculum for school leadership development is emerging (Bush \& Glover, 2004; Patterson \& West-Burnham, 2005). However, the researcher cautions against this situation becoming a reality. Issues of context, culture and curricula should be taken into consideration when designing leadership development curricula. The 'copy and paste' model employed at ADEC is a good example of a system designed for the Western, and more specifically, the American market, which is not necessarily suitable in the context to which it has been applied.

An exploration of the content of professional development programmes reveals that many educational leadership programmes are weighted toward day-to-day managerial, operational tasks requiring technical or operational knowledge, rather than instructional leadership, with its focus on strategic leadership development (Hess \& Kelly, 2007). It is, therefore, suggested that programmes should contain both managerial and leadership content (Patterson \& West-Burnham, 2005). This proposal is aligned with the framework developed for this study, suggesting that the roles are integrated, which relies on both these content areas as part of the newly proposed programmes. Three skill sets are proposed in the context of the induction and mentorship of effective School Administrators: instructional leadership, professional socialisation and organisational socialisation (Doyle \& Rice, 2001). The Sergiovanni model (detailed above) proposes five domains of leadership, which may form the basis of a leadership development instructional programme content namely: Technical, Human, Cultural, Symbolic, and Educational Leadership (Sergiovanni, 2001).

The school leader needs to be able to move between strategic (leadership) activities and organisational (managerial) activities during a normal school day. Heystek (2014) notes that the role definition and expectations of senior school leaders in each school may vary and therefore these different contextual roles determine the extent to which the senior school 
leaders perceive their roles to be either that of a manager or a leader. Bond (2013) suggest that the senior school leaders in Abu Dhabi, perceive themselves to be leaders. The role of senior school leader in a centralised system may suggest otherwise. Very little strategic decision making on school level takes place in schools. The decision making restriction force the school leaders to act in an operational managerial protocol, suggesting that the role perceptions and understanding of their roles may be investigated. This constant change in roles requires the senior school leaders to engage in multiple levels of decision making during the day. A lack of experience associated with appointing young highly qualified leaders exacerbate an inability to move between the strategic and managerial functions of the role. Thus, senior school leaders need to find ways to engage in both the strategic function of leading and the operational day-to-day function of their roles, in order to successfully manage their school. It is therefore critical to the development of any newly appointed senior school leader, that they are well-trained and prepared for both the operational and strategic leadership functions (Heystek, 2014).

\section{Research Methodology}

The data for this paper was constructed using a mixed-method approach. Themed and structured questionnaire surveys were used, followed by individual interviews that discuss the perceived needs of twenty newly appointed senior school leaders from schools in diverse socio-economic communities in the Western Cape and Abu Dhabi. The structured questionnaire survey, which was adapted from a variety of leadership development frameworks (Cranston et al. 2003; Hess \& Kelly 2007; Piggot-Irvine et al 2013) as well as the Norms and Standards for Educators from the DoE (2011) sought, among other things, to ascertain the novice school leaders' role perceptions shortly after their appointment to a senior leadership position. Using the data from the surveys, individual interviews were conducted to clarify the survey responses and enrich the data. The responses were transcribed and coded to reveal patterns. This paper reports on the perceived role and responsibility perceptions of the twenty selected newly appointed senior school leaders from the Western Cape, South Africa and Abu Dhabi, UAE.

The data collected during this study draws from an investigation into five leadership functions as described by the Cranston et al. (2003) and the adapted functions by Jansen van Vuuren (2016), the five main areas for both this study and previous studies as identified by the author were:

- Leading strategic initiatives

- Leading teaching and learning

- Leading the organisation

- Leading people (staff)

- Leading the community

The following areas within these leadership functions were investigated:

- Roles and responsibilities perceptions (Strategic Functions) 
- Roles and responsibilities perceptions (Operational Functions)

A five point Likert scale is used to collect and structure the data identifying the various perceived role perceptions of the respondents at both the Western Cape and Abu Dhabi.

The following section reports on findings of this study and details the perceived roles and responsibilities of newly appointed senior school leaders by using the five leadership functions described previously.

\section{The Findings of the Study}

In this section, the results from the investigation into the perceived strategic and organisational roles and responsibilities of newly appointed senior school leaders in the two cases are compared and analysed.

The data reveals a high priority perception in both the 'Leading strategically' and in the, 'Leading and Managing the Administration' functions in both cases. This perception of school administration is supported by a study conducted by Hoadley et al. (2009) in 142 schools, which shows that Principals report spending most of their time on administrative functions and on disciplining learners. It is for this reason that the respondents perceive that this is a high priority in their new roles. The Abu Dhabi respondents perceive that they are not engaged in the 'Leading Strategically' function of leadership but rather spent most of their time on Operational and Administration issues, which is confirmed during the interviews.

\section{Strategic Role Perceptions}

The Abu Dhabi and Western Cape data reveal that the newly appointed senior school leaders suggest a ten per cent difference between the ADEC and WCED Strategic Role perceptions. The reason for this difference might be that the newly appointed Abu Dhabi senior school leaders work in a highly centralised system with diminished responsibility for school-based strategic planning when authorising budgets, staff appointments and general decision making that affects the school in the long term. The Abu Dhabi central office makes all strategic decisions and provides direction to the schools for implementation. The Abu Dhabi Principals suggest during interviews that they are perceived as managers and not school leaders. They suggest that there is very little being done to help them develop as strategic leaders whereby they would be permitted to make their own strategic decisions for their particular school context.

\section{Leading Professional Development as a Strategic Leadership Function Perceptions}

The comparative data reveal that the Abu Dhabi respondents (40 per cent) suggest they do not perceive leading professional development to be part of their role as a senior school leader. The data from the interviews confirm that the ADEC senior school leaders seldom have the opportunity to develop their own school staff according to their needs. This is a new concept for the Abu Dhabi schools. As a result of them outsourcing professional development, the Abu Dhabi newly appointed senior school leaders agree that professional development is not their responsibility. This results in a moderate to very low perception of the need to conduct his or her own professional development. 
The Abu Dhabi senior school leadership have no choice as to whether or not to participate in training. The centralised system at Abu Dhabi dictates most of their professional development training. This practice was revised slightly in the last term of 2015 when schools were granted permission to plan some professional development activities, although central office is still restricting the practice and content of material that is allowed.

In the Western Cape, by contrast above 95 per cent of the respondents suggest they perceive 'leading professional development' as an important part of their position. The Cape Teacher and Leadership Institute (CTLI) offer courses on behalf of the Western Cape education department. The Western Cape Education Department (WCED) respondents suggest that these courses from CTLI are undertaken on a voluntary basis, free of charge, as per the need, and may be taken during work time. The schools provide their own school- based contextualised professional development to staff in order to supplement the CTLI programmes. The data from this study reveals that due to the long-standing practice in the WCED, the newly appointed senior school leaders perceive local in-house professional development presentation to be a normal function of their roles.

The ADEC respondent's surveys reveal that they have many years of professional development training by external companies. Some of the respondents had their own coaches and mentors in some of the previous development programmes. The focus of this professional development coaching and mentoring was to improve both the strategic functions and the leading the organisational management functions in the school. These programmes offered in Abu Dhabi seek to develop school leadership capacity at all levels. As a result of the centralised system, the respondents suggest that the time in developing them as strategic leaders is not useful since they are not given the opportunity to apply their newly acquired skills. They suggest that all strategic decision-making be removed from their realm of responsibility, supporting their perception that senior school leaders are merely treated as school-based managers. It is reasonable to suggest that as a result of this practice, newly appointed senior school leaders rate themselves lower in all the strategic leadership functions.

In contrast with the Abu Dhabi practice, the WCED respondents suggest that the WCED expects their new senior school leaders to engage in all levels of strategic decision-making. The WCED newly appointed senior school leaders indicate that they receive no training in developing themselves as strategic leaders, although they report that they are expected to take full leadership and managerial responsibility for this function in their schools. This practice from the WCED, although juxtaposed to the Abu Dhabi experience, leaves them just as frustrated as their colleagues at Abu Dhabi, since they do not feel fully competent in this leadership function due to the lack of appropriate training and support. It may be suggested that the practice in both systems does not support the optimal growth of their senior school leaders. Moreover, the conclusion may be drawn that school support practices in both the Abu Dhabi and WCED systems are in need of significant restructuring to ensure success in sustainable and improved leadership capacity.

The data indicate some conflict between the perceptions of the roles and responsibilities of the position and that the reality of the position create a stressful and uncertain first term after 
appointment for the new senior school leaders. The senior school leaders in the WCED indicate, as previously discussed, that they experience high levels of stress because they do not receive enough support in their new roles. The comments below from newly appointed leaders illustrate this frustration. Miss DL, a newly appointed Vice-Principal at the WCED, states:

There was no hand over period, which made things very difficult for me.

The Vice-Principals at Abu Dhabi experienced the same difficulties. Mrs $\mathrm{H}$, a newly appointed Vice-Principal I Abu Dhabi, comments:

I did everything, I did what I think was my focus. No one told me what I should do. They just transferred the (Principal)... that was experienced and put me here, in a big new school with no help. Even though I did not have any outside leadership training.

Mr D, a newly appointed Principal in the WCED, agrees with this statement, saying:

I was just dumped into a situation. I had to basically put things together for myself without any help... but there is a lack in the education department in that there is not enough training. The WCED must have programmes in the beginning for the new Principals.

During the interviews, the respondents are asked to explain what they do on a normal day. It is interesting to note that some of the respondents indicate during the interviews that they do not spend any time on strategic planning with other staff members. Their days are filled with operational issues and the only planning they are involved in is short term planning relating to current issues.

The respondents in both the cases suggest that there is an assumption from both the Abu Dhabi and WCED systems that newly appointed leaders are ready to fully engage in their new positions. The data from this study indicate that newly appointed school leaders in the WCED and Abu Dhabi in fact perceive that they are not well prepared for their role nor are they able to provide adequate leadership direction in their schools during the first term/semester after appointment.

The WCED data suggests that leaders require school-based coaching and mentoring during the first term/semester. This is supported with a statement from Miss DL, a newly appointed Vice Principal at the WCED, who said:

I wish I had someone that could work with me during the first term to help me find my feet

Mrs MA, a newly appointed Vice-Principal in Abu Dhabi, suggests that:

Having an experienced Principal works with me or even if I could shadow an experienced person would have helped me during that first couple of months. It was very difficult and I made many mistakes.

The newly appointed senior school leaders in both systems suggest that leadership and operational management are priorities for them, while they express their concern that they are not able to provide these leadership functions directly after their appointment, since they are 
not well prepared for their roles and due to the lack of preparatory support.

It is widely understood that the role of the Principal includes instructional leadership and overseeing curriculum implementation and monitoring of student success (Osman \& Mukuma, 2013). In the ADEC study, 90 per cent of the respondents indicate that they perceive the management of the curriculum and instructional leadership to be an important part of their role. In the WCED the respondents suggest during the follow up interviews that that Curriculum Leadership should be the focus of their role since they are required to teach as part of their daily duties. They perceive managing the teaching and learning function as integral to their role. In a study of Gauteng Principals by Hoadley (2009), the data collected indicate that only 17 per cent of their Principals focus on Curriculum Leadership elements of the role of Vice-Principal and Principal, concurring with the results from this study. This suggests that there is a great divide between perception and reality of the function of the senior school leader.

The newly appointed senior school leaders perceive themselves as competent in most leadership functions. These are: Leading Strategically, Leading the organisation, Leading teaching and learning, Leading people and Leading the community. Both Abu Dhabi and the WCED report a great need for development in these functions, suggesting that there is a possible gap between the reality of the role and their perception of the role. Their perceived competencies, knowledge and understanding do not match what they require in terms of development needs. These aforementioned competencies are also perceived as areas for further development highlighting that the new leaders do not really know what they do not know.

The results from this investigation suggest very similar 'roles and responsibilities', and 'competency' perceptions when the sections on 'roles' are compared between Abu Dhabi and the WCED new senior leaders. Interestingly the study group indicate a high level of perceived competence, but in another question which didn't form part of this investigation, the same group indicated that they require much training in the same fields.

When questioned about their perceptions of dealing with community and conducting parent interviews both the WCED and ADEC respondents suggest that they do not perceive this to be central to the role of the senior school leader. The newly appointed senior school leaders from both countries agree that dealing with parents is a complex task, and they expressed concern that they never received any training to deal with complex parental pastoral issues. This concern creates daily stress for both groups, since they believe they are required to spend a great deal of their time consulting with parents in difficult situations. A general consensus from the group is that this makes them feel vulnerable and insecure in their decision-making. They all agree that the success of their schools lies in the involvement and participation of the parents and the level of support they get from them. Interestingly some of the respondents concurred and commented that most of their students use busses to travel long distances to school and they suggest that this limits parent involvement, which in turn, complicates some aspects of their roles. One of the respondents concur with them while also commenting that at one of the most frustrating things for her is dealing with parents. They suggest some are disrespectful in the demands they make on her time and should be educated 
to understand her role. The majority of the respondents agrees that having good community involvement in the school assists with solving local contextualised problems. In a study conducted by Piggot-Irvine et al. (2013) with Principals in Gauteng Province, South Africa, their respondents indicate they spend much more time than what they had anticipated on solving problems and dealing with parents. These findings support the findings of this study suggesting that the new senior leaders spend a great deal of time on the day-to-day operational activities. The newly appointed senior school leaders, despite this issue, suggest that they want more parent involvement. Throughout this study, the respondents in both cases suggest that they have mixed results in dealing with parents, while commenting that this aspect of the role contributes greatly to the pressure they experience during the first couple of months after appointment.

\section{Organisational Leadership Function Role Perceptions}

The comparative data suggest that the day-to-day organisational functions of leadership, from both cases require further support and development when leading and managing the communities in their local contexts. One may argue that the successful newly appointed senior school leaders requires community support in order to improve student attainment in their schools. This argument is supported in the literature when Blumberg \& Greenfield (1980) make the following suggestion about the Principal:

$\mathrm{He}$ [sic] is the main link between the school and the community and the way he performs in that capacity largely determines the attitudes of students and parents about the school. If a school is a vibrant, innovative, child-centered place; if it has a reputation for excellent in teaching; if students are performing to the best of their ability one can almost always point to the Principal's leadership as the key to success (Blumberg \& Greenfield, 1980:44)

Throughout this study, the respondents in both cases suggest that they have mixed results in dealing with parents, while commenting that this aspect of the role contributes greatly to the pressure they experience during the first couple of months after appointment.

\section{Comparative Organisational Function Role Perceptions}

The data suggest that the respondents from both cases express the desire not to deal directly with parents or any parent matters, since it can be very time consuming and requires input into matters they are not trained for.

The respondents indicate that they strongly perceive their roles to be a strategic leader at ADEC while more of an organisational leader at WCED. The respondents expressed their concern with the fact they are busy with the day-to-day tasks and immediate issues that arise at school leaving them with no real strategic leadership time. This is especially true for the ADEC respondents as they are inclined to perceive their roles as more strategic and less organisational. In reality the data suggests, this is not the case since they are also occupied with day-to-day issues that arise, as is the case with the WCED respondents as seen from their quotations provided in these chapters. The respondents in both cases suggest that the 
day-today activity that takes up most of their time, such as dealing with parents and teachers that demand their time leaving them with little time to concentrate on the real organisational tasks. Ms DL a respondent at the WCED suggest that she has to work long hours as a result of this, only attending to her 'real job' in the afternoons and early mornings. Ms DA at ADEC suggests that the fact that parents and staff constantly demand her time without appointments force her to neglect some of her organisational activities.

\section{Perceptions of Roles and Responsibilities of the Leadership Positions by Newly}

\section{Appointed Senior School Leaders at ADEC and WCED: Summary of Main Findings}

The comparative findings reveal that there are great similarities between many aspects of the perceived roles and responsibilities, competencies and the professional development needs of the respondents from both countries.

The comparative data indicate that the respondents have a good perceived understanding of their senior school leadership roles and understanding of their different roles within the school. The comparison also exposes some conflict between the perceived understanding of the role and the reality of the role. The respondents report that the conflict is caused by the lack of role definitions, and the actual requirements of the senior school leader role in both cases. The respondents report that very few of them ever received a job description, leading them to echo the perception that their new roles are not what they thought they would be, which they suggest is a main contributor to their role confusion.

\section{Reference}

Blumberg, A., \& Greenfield, W. (1980). The effective principal: perspective on school leadership. Boston, MA: Allan and Bacon, Inc.

Bond, S. (2013). Leadership development in the context of the United Arab Emirates: participant perceptions in the professional development program. Unpublished $\mathrm{PhD}$ thesis, Florida University, Florida.

Bush, T., \& Glover, T. (2004). Leadership development: evidence and beliefs. London: National College for School Leadership.

Bush, T. 2007. Educational leadership and management: theory, policy and practice. South African Journal of Education, 27(3), 391-406.

Cranston, N., Ehrich, L. \& Kimber, M., (2003). The 'right' decision? Towards an understanding of ethical dilemmas for school leaders. Westminster Studies in Education, $26(2), 135-147$.

Desimone, L. M. (2009). Improving impact studies of teachers' professional development: toward better conceptualizations and measures. Educational Researcher, 38(3), 181.

DOE. (2011, April 05). Intergrated Strategic Planning Framework for Teacher Education and Development in south Africa. Retrieved October 01, 2015 from Education.gov.za: www.gov.za/LinkClick.aspx?fileticket+ZF\%F6rDGMIFM\%3D\&tabid+358\&mid=2316 
Doyle, M., \& Rice, M. D. (2001). A model for instructional leadership. Retrieved March 21, 2013 from Principal leadership: http://nassp.org/pl_model_1102.html

Elmore, R. (2000). Building a new structure for school improvement. Washington, DC: The Albert Shanker Institute.

Fullan, M. (2006). Turnaround leadership. San Francisco, CA: Jossey-Bass.

Fullan, M. (2014). Leading in a culture of change. San Francisco, CA: Jossey-Bass.

Guskey, T. (2003). What makes professional development effective? The Phi Delta Kappan, 90(7), 495-500. https://doi.org/10.1177/003172170909000709

Hargreaves, D. (2006). Personalising learning 6: the final gateway: school design and organisation. London: Specialist Schools Trust.

Hart, A. (1993). Principal succession: Establishing leadership in schools. New York: SUNY press.

Hess, F. (2003). A licence to lead? A new leadership Agenda for Americas Schools. Washington DC, Washington, DC: Progressive Policy Institute.

Hess, M., \& Kelly, A. (2007). Learning to lead. What gets taught in Principal preperation programs. Olin Foundation. PEPG.

Heystek, J. (2014). Principals' perceptions about performance agreements as motivational action: Evidence from South Africa. Educational Management Administration Leadership, 42(6), 889-902.

Heystek, J., \& Lumby, J. (2011). Identity and diversity: A case Study of leaders in a South African primary school.

Hoadley, U., Christie, P., \& Ward, C. L. (2009). Managing to learn: Instructional Leadership in South african Secondary schools, . Leadership and Management, 29(4), 373-389. https://doi.org/10.1080/13632430903152054

Hoy, W., \& Miskel, C. G. (2008). Educational Administration: Theory, research, and Practice (8th ed.). New York: McGraw-hill.

Jansen, J. (2016, 12 10). Business Tech (2016). Retrieved 01 14, 2017 from Ten ways to improve South Africa's education System/: https://businesstech.co.za/news/general/108181/10-ways-to-improve-south-africa's-education -system

Kotter, P. (1990). How Leadership Differs from management. The free press.

Leithwood, K., \& Riehl, C. (2003). What we know about successfull school leadership. (L. f. Success, Ed.) Philadelphia: Temple University.

McCauley, C.D., Moxley, R.S. \& Van Velsor, E. 1998. The center for creative leadership handbook of leadership development. San Francisco: Jossey-Bass. 


\section{Macrothink}

International Journal of Human Resource Studies

ISSN 2162-3058

2018, Vol. 8, No. 3

Murphy, J. (2001). The changing Face of Leadership Preperation. School administrator, $58(10)$.

Normore, A. (2004). Socializing school administrators to meet leadership challenges that doom all but the most heroic and talented leaders to failure. International leadership journal in education, theory and practice, 7(2), 107-125.

Osman, A. \& Mukuna, T. E. (2013). Improving instructional leadership in schools through building principals' capacities. Journal of Education and Practice, 4(2), 41-47.

Patterson, P., \& West-Burnham, J. (2005). Developing begining leadership. In M. Coles, \& Southworth, G. Developing leadership: creating the schools of tomorrow (pp. 108-126). Open University Press.

Piggot, I. E., Howse, J., \& Richard, V. (2013). South African Principal And Development needs. ISEA, 41(3), 55-72.

Quint, J., Akey, T. M., Rappaport, S., \& Wilner, C. J. (2007). Instructional Leadership, Teaching Quality, and Student Achievement Suggestive evidence from urban districts. Department of Education, NY. Department of Education, Washingrton DC.

Renihan, P. (2012). Leadership succession for Tomorrow's school. Procedia- Social and Behavioural Sciences, 55, 138-147. https://doi.org/10.1016/j.sbspro.2012.09.487

Roza, M. (2003). A matter of Definition: Is there Truly a Shortage of School Principals? Washing University. Seattle: Center on Reinventing Public Education.

Sergiovanni, T. (2001). The principalship: A reflective practice perspective. Needham Hights: MA: Allyn and Bacon.

Sutcliffe, J. (2013, 08 13). The Guardian. Retrieved 01 14, 2017 from Teacher blog: https://www.theguardian.com/teacher-network/teacher-blog/2013/sep/24/eight qualities-succesful-school-leaders

Tucker, M. (2003). Out with the old. Education Next 3, 4, $20-24$.

WCED. See Western Cape Education Department.

Western Cape Education Department. 2015. WCED website. http://wced.pgwc.gov.za/home/home.html [30 April 2016].

\section{Copyright Disclaimer}

Copyright for this article is retained by the author(s), with first publication rights granted to the journal.

This is an open-access article distributed under the terms and conditions of the Creative Commons Attribution license (http://creativecommons.org/licenses/by/4.0/). 